\title{
Fees, funding and overseas study: \\ mobile UK students and educational inequalities
}

\author{
Rachel Brooks and Johanna Waters
}

\section{Published in Sociological Research Online, May 2011}

\section{Introduction}

An article in The Guardian in 2006 claimed that: 'some bright students have found an answer to the fees nightmare: in Europe' (Clark, 2006). It went on to argue that the introduction of variable fees in the UK in 2006 had encouraged some UK students to consider moving overseas for their degrees and, in particular, to European countries such as Sweden and the Netherlands, which charged low fees or no fees at all. While there have been a small number of further press reports which have indicated that changes to the funding of higher education in the UK have encouraged more young people to consider seriously the possibility of studying abroad (for example, Brill, 2006, Vedrickas, 2010), we still know relatively little about the impact of financial factors on a decision to pursue a degree overseas. It is likely, however, that with the introduction of significantly higher tuition fees in the UK from 2012 onwards (as a result of the government's response to the Browne Report (2010)), students will be more likely than ever before to seek out cheaper fees abroad.

Although many researchers have explored the economic rewards which often accrue in the medium- or long-term as a result of overseas study (Ong, 1999; Waters, 2008), the academic 
literature has much less to say about both the impact of fee differentials on young people's decision-making, and the resources upon which they draw to fund a period of study overseas. In an attempt to redress this gap, this paper draws on data from a qualitative study of young UK citizens who had either completed a degree abroad, or were seriously considering moving overseas for this purpose, to explore the impact of short-term economic calculations on their decisions, and the sources of funding upon which they drew. In doing so, we argue, firstly, that there are important differences between mobile students: those who moved abroad for an undergraduate degree tended to be from more privileged backgrounds than those who moved for postgraduate studies and, as a result, considerably less sensitive to price differentials. Secondly, we suggest that, despite important differences in economic capital, both undergraduates and postgraduates were able to draw on significant cultural resources. This raises questions about the extent to which overseas opportunities can be opened up more widely, to include a greater cross-section of young people. First, through, we provide some context to the discussion that follows by outlining recent changes to the way in which higher education is funded and exploring inter- and intra-national differences.

\section{The cost of an (international) education}

Historically, the development of higher education, in many countries of the world, has been predicated on the assumption that higher education is a social good, which benefits wider society as well as the individual students themselves. Thus, it has been assumed that the costs should be borne by society and free higher education should be provided, as a fundamental right, to all those who are qualified (Marcucci and Johnstone, 2007). The past two decades have, however, witnessed a significant rethinking of these assumptions. Students and their families have, increasingly, been asked to share at least part of the costs of their higher 
education. This can be seen as a result of the shift from social democracy - in which the main form of social provision was through the state, and social welfare was accorded high importance as a means of addressing inequalities - to neo-liberalism - in which the market has become the main mechanism for the delivery of services, and social welfare is seen as merely a safety net. As part of the justification for these new arrangements, politicians and other policymakers have emphasised: the considerable private returns to higher education, which accrue to the individual student in later life through increased earnings; the difficulty of raising taxes to meet the growing costs of higher education; and the increase in standards of university education as students come to behave as consumers, and greater competition is introduced within the system (Brown, 2011; Lunt, 2010). Moreover, in many countries, other social needs have often come to take precedence, as Johnstone (2004) notes:

Governments are also besieged with other pressing public needs, many of which seem more politically compelling than the claims of higher education and which, together with higher education, greatly exceed, in almost all countries, the available scarce public resources. The result is an increasing sense of austerity within the higher educational systems of most countries and a heightened appreciation of the importance of other-than-governmental revenue. (p.403)

From a different position on the political spectrum, it has also been argued that traditional models of funding are frequently regressive, as it is often largely the most privileged sections of society who benefit from higher education, while the costs are borne by all social groups through the taxation system (Marcucci and Johnstone, 2007). As a result of these changing assumptions about higher education and, in particular, the increasing dominance of a neoliberal agenda, mechanisms for funding universities have changed significantly. The 
proportion of higher education costs covered by the state, through general taxation, has declined, and increasing reliance has come to be placed on contributions from students and, in some cases, their parents (Ertl, 2005; Johnstone, 2007; Li, 2007; Lunt, 2010; McMullen, 2004; Welsh, 2009).

While there has, in general, been a shift towards greater 'cost-sharing' worldwide, there remains considerable variation in the way in which higher education is funded, evident in the various typologies of approaches to funding tertiary education that have been developed. The OECD's (2010) version is based on two dimensions: the extent to which costs are shared by the student and/or his or her family, and the nature of any student support mechanisms that are in place. Four distinct clusters of countries emerge from this analysis: firstly, those with no or low tuition fees and quite generous student support systems (for example, the Nordic countries); secondly, those with high levels of tuition fees and well-developed student support systems (including Australia, Canada, the USA, New Zealand and the UK); thirdly, those with high levels of tuition fees but less developed student support systems (such as Japan and Korea); and, finally, those with low tuition fees and less developed provision for supporting students (many European countries with the exception of those mentioned above). In many ways, the type of tuition fee policy adopted by an individual country can be explained by common national assumptions about appropriate parental responsibility (Marcucci and Johnstone, 2007). For example, in Scandinavian countries in which no fees are payable, higher education is typically assumed to be a social good, benefitting the whole of society, and so the state pays for the costs of tuition through general taxation. In contrast, assumptions that parents have a responsibility for their child's education and should pay according to their ability underpin systems which require up-front fees, such as the US, Austria and Chile (ibid.). Countries such as New Zealand, Australia and England, which have 
a deferred tuition policy, tend to assume that parents are not financially responsible for the child's higher education, and that young people cannot be expected to cover the costs themselves while they are studying (ibid.). The dominant political ideology is also clearly important: there is a good correlation between the OECD clusters and the typology of 'welfare regimes' developed by Esping-Anderson (1990). Thus, those countries which retain a strong social democratic welfare state are typically those which have no or low fees and high levels of student support, while those that are more strongly neo-liberal in orientation have introduced relatively high fees. Political differences within countries are, however, also significant: within Germany, for example, it is mainly the Länder with right-leaning governments that have introduced tuition fees (Welsh, 2007).

Although Marcucci and Johnstone (2007) contend that 'little is known worldwide about the impact of cost sharing (and tuition fees) on higher education accessibility and enrolment behaviour, or about the ameliorative efficiency of programmes such as means-tested grants and loans' (p.38), the OECD argues that the availability and quality of student support in any one country is a better predictor of average entry levels to higher education than the level of tuition fees. While those countries with no/low tuition fees and generous student support packages tend to have the highest average entry rates, countries with high fees and welldeveloped student support systems typically have higher rates than those with low/no fees and less developed student support. The OECD (2010) thus concludes that "while high tuition fees can raise potential barriers to student participation, this suggests that the absence of tuition fees, which is assumed to ease access to education, does not necessarily ensure high levels of access and quality' (p.251). Other studies (conducted in different parts of the world) have put forward a similar argument, suggesting that the introduction of tuition fees is not 
necessarily inequitable if a significant support package is available to students (Biffl and Isaac, 2002; Ferreira and Farkas, 2009; Vossensteyn, 2000, Weiler, 2000).

However, there is some evidence of geographical disparities in these effects, even within the same country 'cluster' in the OECD typology. For example, Marcucci and Johnstone (2007) claim that the introduction of tuition fees has had a different effect on the socio-economic composition of the student body in the UK and US when compared to Australia and New Zealand. Moreover, they suggest that some effects on students in response to the increasing costs of higher education may not be picked up by the macro-level data which are often relied upon - for example, a switch to: cheaper universities, part-time study, living at home rather than in university accommodation and working longer hours in paid employment. Certainly, within the UK context, there is strong evidence to suggest that the introduction of tuition fees had a considerable impact on students' choice of university (Callender and Jackson, 2008). Moreover, Callender's (2010) detailed research on the allocation of financial aid in the UK (through the bursaries awarded by individual institutions) indicates that money which is supposed to be devoted to promoting greater access is often used for other ends (see also McCaig, 2009). Her work demonstrates that many universities 'assumed an instrumental view of non-mandatory bursaries and scholarships...using this student support as part of a competitive strategy both to widen participation and to assist their repositioning in an increasingly competitive marketplace' (p.56). Bursaries were thus often used to attract certain types of student (such as high achievers) and protect the institution's market share, rather than increase the participation of low-income groups.

Variations in tuition fees within a single country can also have a differential effect by social group. For example, $\mathrm{Li}$ (2007) explains how, in China, tuition fees are lower in higher status 
institutions. Due to the correlation between socio-economic status and academic attainment, students from higher status families tend to monopolise the higher status universities. Thus, Li (2007) claims 'There is...a reverse relationship between family affordability and cost burdens. Lower income families are taking on much higher burdens for their children's education than higher income families, and these burdens have a negative influence on the quality of life of lower income families' (p.734). Similar consequences have been noted in Latin American countries, which have seen the rise of lower-status private institutions, which charge high fees, alongside prestigious public universities, which charge low or no fees (Johnstone, 2004).

Similar within-country fee variation can also be seen in relation the different ways in which domestic and international students are treated. In a number of countries - such as Australia and many European Union nations - a 'dual track' system has been introduced, whereby international students or, in the case of some EU countries, those from outside the EU, pay considerably higher tuition fees than even full fee-paying domestic students (Marcucci and Johnstone, 2007). In 2010, for example, in the UK, domestic students paid annual fees of $£ 3290$, while overseas fees varied by institution but were typically substantially higher - at around $£ 10000$. Similarly, in Australia, domestic fees (the 'student contribution') in 2010 ranged from $\mathrm{A} \$ 0$ to around $\mathrm{A} \$ 9000$, while fees for international students often exceeded A $\$ 21000$ (over $£ 13000$ ). Indeed, revenue from overseas students has become increasingly important to many higher education systems worldwide, as domestic funding has been reduced. In Australia, federal government funding for universities declined by 30 per cent between 1995 and 2000. Over this period, international students were pursued vigorously as a means of addressing the shortfall and, by 2003, cross-border student fees provided over 14 per cent of higher education revenues (Deumert et al., 2005). As Australia has not been alone 
in adopting this type of approach, a fierce global competition for international students has emerged, with nation-states and individual universities deploying increasingly sophisticated branding and marketing techniques to entice students overseas (Lunt, 2010; Sidhu, 2006). Recently, Western nations have been joined by countries in other parts of the world, keen to in a segment of the lucrative international student market.

It would, however, be wrong to assume that all countries are following the same trajectory. Despite claims about the 'globalisation' of education policy and the homogenising effects of neo-liberalism, there remain important variations by nation state (Brooks and Waters, 2011). This is notable even within the European Union. As noted above, the UK has devoted considerable resources to attracting overseas students to its universities, and maintaining a substantial differential between home and overseas fees. This has led Sir Drummond Bone, the former vice-chancellor of the University of Liverpool and government adviser on internationalisation to argue that:

From the point of view of overseas governments and perhaps at least as importantly the press overseas, the main problem with the UK is a perception that our universities are solely interested in international students as a source of revenue. $(2008$, p.3)

They are therefore seen as less interested in promoting outward flows. In contrast, however, Denmark has recently implemented a very different policy with respect to student mobility (Salskov-Iverson, 2010). As a result of concerns that, while it was attracting large numbers of overseas students, its own population showed little inclination to move abroad for higher education, in 2008 it introduced an 'International Scholarship Programme' to promote outward mobility. Under this scheme, students studying abroad receive a scholarship to cover 
their fees in their destination country equivalent to the amount the state would have paid to their university if they had remained in Denmark. This resulted in an increase in outward mobility amongst Danish students of about ten per cent almost immediately (Salskov-Iverson, 2010).

This Danish policy suggests that students' decisions whether or not to move abroad for higher education are influenced, at least to some extent, by fee levels. However, as noted above, within the growing literature on student mobility - within the disciplines of sociology, education and geography - relatively little attention has been paid to the impact of fee differentials between countries, or indeed about the sources of funding mobile students draw upon to facilitate their study abroad. In beginning to redress this gap, in the subsequent sections of this paper we explore the impact of financial considerations on the decisions of UK students who had either already studied for a degree abroad or were seriously considering doing so. First, however, we discuss the dataset upon which our analysis is based.

\section{Research methods}

This paper draws on in-depth, qualitative interviews that were conducted with 85 young men and women who had studied abroad for the whole of an undergraduate or postgraduate degree, or were seriously considering doing so in the near future ${ }^{\mathrm{i}}$. Interviewees were recruited through a wide variety of channels, including: schools, colleges, universities and careers advice centres; large, UK-based companies; alumni associations of overseas universities; organisations which offer scholarships for study abroad; a higher education fair organised by the Fulbright Commission; and 'snowballing' through our own personal networks. As well as achieving a good balance between undergraduate and postgraduate modes of study, and 
between young people who had completed a period abroad and those who were seriously considering it (see Table 1), our sample was also reasonably balanced in terms of gender comprising 37 young women and 48 young men. It also included 22 respondents from minority ethnic backgrounds. The sample was, however, much less balanced in terms of the socio-economic status of respondents: those from affluent backgrounds with very successful academic careers were over-represented across the sample as a whole. However, we do not consider this to be an artefact of our sampling methods: other studies on the mobility of UK students have also pointed to the particularly high socio-economic status of those who study abroad for the whole of a degree and the dominance of those from private school backgrounds ${ }^{\text {ii }}$ (Findlay and King, 2010), and research on UK participation in Erasmus schemes has reached a similar conclusion (Sussex Centre for Migration Research, 2004). There were, however, important differences between our undergraduate and postgraduate sample, which have some bearing on the arguments developed later in the paper: for example, while almost two-thirds of the undergraduate sample had attended a private school, only just over a fifth of the postgraduate sample had done so. The postgraduate sample also included more students from lower socio-economic groups and who had experienced more varied educational histories (for example, returning to higher education as a mature student).

[Insert Table 1 here]

Interviews were conducted with the respondents between September 2007 and February 2008 and included questions about: reasons for becoming interested in overseas study; expectations of life as an overseas student; the role of family, school and friends in the decision-making process; and previous experiences of travel. Those who had already completed their degree overseas were also asked about their experiences of being abroad and of entering the graduate 
labour market. All respondents were asked a series of questions about how they had funded their overseas degree (or how they were planning to), and about the extent to which their decision-making had been affected by financial considerations. It is the responses to these last two sets of questions which provide the basis for the discussion in the remainder of this paper. In the sections that follow, we identify two contrasting attitudes in relation to the cost of overseas study, which emerged from our analysis of this dataset.

\section{Price sensitivity}

\section{Fee differentials and scholarships}

When deciding whether or not to move abroad for their higher education, the narratives of a substantial number of our respondents suggested that they had been sensitive to price differentials between countries and, for some, their decision to study overseas was motivated, at least in part, by the attraction of significantly lower fees - particularly in Scandinavian countries and other European nations, such as the Netherlands. The quotations below are representative of this group of respondents:

In Finland you don't pay any fees for a master's degree, so that's a kind of a really big selling point from their point of view whereas in the UK you'd have to pay quite a lot more.... I wouldn't have done a master's if I'd been in the UK, purely because I would have had to pay for it....even if you take into account the cost of the occasional flight back at Christmas or whatever, it still worked out much cheaper than studying in the UK.

(Hayley, MA in Geography at Joensuu University, Finland) 
Sweden is probably the only place where I'm going to be able to get like a good quality education for free...money is obviously like a big factor....I looked at masters [in the UK] and just the costs of them, like it's a minimum of $£ 5000$ and I can’t afford $£ 5000$ up front.

(Maxwell, considering an MA in Politics in Sweden)

The costs of studying for a master's degree abroad, you know, is substantially, substantially cheaper than the UK.....I mean even if I was going to get a slightly lesser quality degree, I would probably still study abroad for purely the social enrichment and for the, you know, the cost. You know, when you actually look at the figures on paper, it's quite ridiculous how much more the UK is actually, you know, charging for tuition.

(Jamie, considering an MA in Politics in France or the Netherlands)

While differences in tuition fees were mentioned as a motivating factor by a considerable number of our sample, some respondents had also been attracted to overseas study by what they perceived to be the greater funding opportunities available outside the UK. This was largely in relation to Anglophone countries such as the US and Canada, as the following quotations from Elizabeth and Denis illustrate:

Trying to get funding for an MA in the humanities [in the UK] is very challenging. So I started to look a bit further afield. America appealed partly for the adventure, partly for the fact that I could carry on taking broad-based studies...and partly because there would be funding opportunities available as well. (Elizabeth, MA in French Literature, University of Pennsylvania, USA) 
What advantages did you think it [overseas study] would offer you at the time?

To put it bluntly, money....One of the things that at the time worried me the most about postgraduate studies was how I was going to pay for it and because the ways that I understood it working in the UK at that time was that you would get a place on a course first and then worry about the funding later. And given my sort of personality traits, I liked the idea of having this guaranteed source of funding that would pay for it, you know, in advance of actually getting a place. (Denis, MA and PhD in Philosophy, University of Toronto, Canada)

It is notable that this group of respondents was comprised largely of postgraduates. As we will discuss in more detail in the later parts of the paper, decisions to move abroad for undergraduate study were, on the whole, not motivated by financial concerns and, for those in our sample, high costs were rarely perceived as any kind of barrier or deterrent.

\section{The funding of overseas study}

We observe a similar split between our undergraduate and postgraduate sample when we consider the ways in which an overseas education was funded. As will be discussed below, those who were seriously considering moving abroad for an undergraduate degree, or had already completed such a qualification, were typically reliant on family finances, and considered this largely unproblematic. In contrast, the postgraduate sample was more sensitive to fee differentials, as noted above, but also drew on a much broader range of funding sources. They were, for example, much more dependent on scholarships than the undergraduate sample. (Although there were a small number of undergraduates who had 
gained, or hoped to gain, sports scholarships to fund their time abroad.) The following types of comment were very common across the dataset:

So how important was it that you got the funding to your decision?

Really important, I wouldn't have been able to afford it otherwise.

(Edgar, MA in Geography, University of British Colombia, Canada)

How influential was it that you got funding to your overall decision?

Very. I don't think I would have done it if I'd have had to have funded myself because that's one of the reasons why I didn't kind of pursue the $\mathrm{PhD}$ idea first time round when I'd been turned down by the ESRC [UK funding council] and told well you really need to get a masters. I didn't sort of fancy trying to fund myself through a masters after three years of university. So the money side of it was important. (Helen, PhD in Politics, EU Institute, Italy)

How influential in making your decision to go to Australia was it that you got funding?

Oh, critical yeah, I wouldn't have been able to do it without the scholarship. (Joanne, PhD in Zoology, Australian National University)

And how influential was [the scholarship] in your decision to study abroad? I wouldn't have been able to study abroad without it. (Mark, MSc in Journalism, Columbia University, USA) 
Self-funding was also mentioned frequently. Many of our respondents had worked for a year, prior to embarking on their course, to save enough money, or worked on a part-time basis throughout their degree. Although, in most cases, these sources seemed adequate to cover the costs incurred abroad, a small number of respondents did describe considerable financial difficulties, evident in these extracts from Elizabeth and Patrick:

I found financially it was much harder than I expected, you know, I was living on a small stipend, there's the myth that America is a cheap place to live, well if you go on holiday and the pound is very strong it is, but if you're living on a very small dollar salary it's quite tough. Most of my peers who were American were borrowing substantially to get by and obviously that was out of the question for me. Family support wasn't available.

(Elizabeth, MA in French Literature, University of Pennsylvania, USA)

So what was it like, all this financial juggling?

Very difficult, yeah, I mean it was very hard.... I had no, very little money at all....I got a job in the university archive in the library there and I worked nineteen and a half hours. Nineteen and a half hours is a kind of break off point because if you work more than that they'd have to give you medical insurance.....So I worked in that job in the archive, but even that job wasn't paying me enough to cover my living expenses, and I was living quite frugally. So I had to go to you know, the dean of students then set me up to meet the St Andrews Society of Illinois and they loaned me $\$ 5,000$ I think it was over a three year period, which I subsequently had to pay them back. (Patrick, MA and PhD in Anthropology, University of Chicago, USA) 
While financial struggles were reported by only a small minority of students, difficulties such as those recounted by Elizabeth and Patrick did cause considerable anxiety for the individuals concerned.

\section{Connections, confidence and cultural capital}

As would, perhaps, be expected, the emphasis put on the financial advantages of studying abroad - in countries which charge no or low tuition fees, or which offer generous scholarships - was much more common amongst those in our sample from less affluent backgrounds and/or who had much less conventionally successful academic histories. Extant research within the UK has demonstrated that students from lower socio-economic groups are more debt-averse than their more privileged counterparts (Callender and Jackson, 2005; Morley and Aynsley, 2007), and so are perhaps more likely to be motivated by the prospect of lower fees and/or more substantial financial aid. In discussing migration in Europe more generally, Favell (2008) has argued that we should not automatically assume that it is the most affluent who are most mobile. Indeed, he contends that it is those from more modest backgrounds but who are socially ambitious, who are the most likely to move to take up new opportunities. He calls these the 'social spiralists': 'provincials who found the competitive route through the capital blocked - monopolised as always by the same national elites' (p.93). He goes on to claim that 'the leap abroad can make all the difference in terms of trajectory, acceleration, lift off' (p.93).

However, our data suggest that, while those who exhibited sensitivity to price differentials were typically located within the less privileged part of the sample, they still had recourse to considerable 'cultural capital' (Bourdieu, 1997), which was highly significant in facilitating their mobility. As we have argued elsewhere (Brooks and Waters, 2010), in many cases, the 
young people's social networks played a critical role in expanding their 'horizons for action' (Hodkinson et al., 1996), such that studying overseas came to be seen as a distinct possibility. While in some cases, events such as a placement year abroad had a profound effect in opening up new (overseas) opportunities to respondents, on the whole, attitudes to travel (and thus studying abroad) seemed to be derived, more typically, from experiences within the family and norms within friendship groups (Brooks and Waters, 2010). It was not always the case that a familial propensity to travel was associated with high levels of economic capital for example, when asked what had got him interested in studying abroad, Fergus (who had studied for an MA in Strategic Studies at the Australian National University) explained that he had always travelled abroad since he was quite young. Although his parents were divorced, and he lived with his mum who had a relatively low income, she prioritised travel: 'she was always, you know, massively keen on holidays, she has to have like at least one holiday, probably two holidays a year'. Nevertheless, we would contend that considerable cultural capital accrues from family travel, which is likely to make moving abroad for a degree a much less daunting prospect than for young people with no such familial experience. For example, Edgar (MA in Geography, University of British Columbia, Canada) had spent numerous school holidays staying with a friend of his mother's in France, and believed this had instilled in him a certain confidence at living abroad: 'I'm sure in some ways, having done it for a little while you knew kind of what it was going to be like, going somewhere where you don't know anyone and you know you'll get by in the end'. Thus, while we would dispute Kenway and Fahey's (2007) claim that the 'cosmopolitan Euro student traveller' is 'emancipated from the constraints of space' (p.168) as a result of his or her economic advantage, we would suggest that even those who moved abroad to lessen the cost of study had significant cultural resources upon which were able to draw. 


\section{Insensitivity to price differentials}

In contrast to the broad patterns described above, our undergraduate sample was characterised by a general insensitivity to fee differentials and to what was, in many cases, the increased costs of studying abroad. Very few had been motivated to consider overseas study because of a desire to pay lower tuition fees or seek funding for their studies that would not have been available in the UK. Moreover, none of those who had moved abroad for undergraduate study mentioned the type of financial struggle experienced by some of our postgraduate sample, described above. In general, very little allusion was made to any financial issue at all. In the vast majority of cases, the young person's family had funded or would be funding their study abroad, and this was typically seen as unproblematic, even when very large sums of money were involved. Indeed, for Yuuna, paying for education was seen as part of 'normal' parental responsibilities:

Oh they're Chinese parents, they pay for everything! .... I mean your education is the foremost important thing to them, they pay for stuff like that....it's just the way it is and I mean I think, yeah, I think most people I know their parents paid for their education, yeah I think so.

(Yuuna, BA in English, Brown University, USA)

Although, in this extract, Yuuna relates this attitude to education to her Chinese heritage, similar comments were made by respondents of a white British ethnicity, as this quotation from Richard illustrates:

OK, so you were funded by your parents in the end? 
Yeah.

How did you feel about that?

A mixture of delight and guilt! I always felt guilty but on the other hand it's you know, it's what parents are there for, to bring up kids and I think they did a pretty good job in the end of it. It took time getting to where I needed to be but I'm sure they're delighted with the end result! So I did feel guilty at the time but I also knew I just had to be there, you know, what choice?

(Richard, BA, St Francis Xavier's, USA)

In a few cases, it appeared that the increasing cost of studying within the UK (as a result of the introduction of variable tuition fees in 2006 (Lunt, 2010)) had made an overseas education seem less expensive, in comparison, than it might have done previously. Richard, for example, explained that 'the way my mum and my dad and I worked it out, I was never going to get a grant anyway, and probably what it would have cost I kind of figured....I'm sure it wouldn't have cost much less anyway in the UK'. However, the majority of our undergraduate sample appeared relatively insensitive to differences in the price of a higher education across national borders. As we have explained elsewhere (Brooks and Waters, 2009), many of these young people were pursuing an overseas education in order to access an elite education that they believed had been closed down to them in the UK (i.e. access to the universities of Oxford or Cambridge) - and were considering only very prestigious institutions in other countries (such as Harvard, Yale and Princeton in the US). Most of our respondents had known that such institutions typically charge high fees. However, in very few cases were such fee levels seen as any kind of deterrent. Indeed, as a relatively large proportion of the sample had attended private secondary schools, the fees of elite overseas universities were often viewed (by the young people and, according to them, also by their 
parents) as comparable to or, in some cases, even cheaper than those they had grown used to paying throughout compulsory education. In this quotation, for example, Paul suggests that as his parents were no longer paying his school fees, they had extra income available to finance his (expensive) university place:

\section{How were you funded to go to Harvard?}

I was funded like largely through my parents because they weren't paying for high school!

How did you feel about your parents paying for your university?

It was like, I mean, mm, I really appreciated it I think! I really didn't want to be in that much [debt], it's a lot of money $\$ 40,000$ a year, so yeah it felt really good that they were actually able to do that....

(Paul, BA in Government and Political Science, Harvard)

Similarly, Sabina appeared to see relatively few differences between the expenditure on her secondary education, and that which she was proposing for her higher education. She explained that the maximum it would cost her parents to fund her proposed law course in the US would be $\$ 60,000$ per year, and that this was little different from the amount they were spending on her at the time of the interview, once her school feels, travel and living costs were taken into consideration: 'They [parents] spend that much here! They spend that much here on me a year, you know, it's still my education!'

In their comparative study of tuition fees across the world, Marcucci and Johnstone (2007) argue that one factor which affects the level at which fees are set are assumptions about what people are prepared to pay - and these differ markedly between countries. They go on to contend that "parents may be thought to be more willing to pay in countries with substantial 
private education, where people are more used to paying for the higher (and sometimes the secondary) education of their children' (p.36). Our research certainly suggests that families who have already paid out a considerable amount for a prestigious private secondary education for their child may see little difference in paying comparable amounts to gain access to an elite higher education abroad. Nevertheless, our work also suggests that there are important differences in assumptions between different social groups within individual countries. While the young people in our undergraduate sample (and their parents) were apparently relatively insensitive to the generally high costs of an overseas higher education, a markedly different picture emerged from those who were considering, or had completed, a postgraduate qualification abroad. In general, the respondents in this second group had come from considerably less privileged backgrounds.

\section{Discussion}

In this paper, we have sought to explore the extent to which financial considerations affect a decision about whether or not to study abroad, and the ways in which mobile students fund their overseas study. Our analysis, presented above, has suggested that there are important disparities between those who cross national borders to pursue an undergraduate degree, and those who move abroad to gain a postgraduate qualification. In general, our undergraduate sample was much more privileged: respondents in this group had excellent academic credentials, very smooth and successful educational histories, and families who were able to offer considerable economic and cultural resources to facilitate studying abroad. Almost twothirds of this group had had a private secondary education. In contrast, the postgraduate sample was more diverse: respondents typically came from less privileged backgrounds and some had had less conventionally successful academic histories. Moreover, a smaller 
proportion had been privately educated. These characteristics help to explain some of the differences between the two parts of the sample in the extent to which they were influenced by financial considerations, and the ways in which they funded their time abroad.

In her work on the mobility of early career scientists, Guth (2008) argues that tuition fee differentials are significant. She cites the example of doctoral students from Poland and Bulgaria who took part in her research who had wanted to study in the UK but had been deterred by the relatively high fees, and had taken up places in Germany instead. Guth also suggests that the reduction in tuition fees for Polish students following Poland's accession to the EU in 2004 had a significant impact on student mobility to the UK: as they became subject to 'home/EU' fees, rather than the much higher 'international' fees', it became substantially easier for individual students themselves to fund the cost of a British degree. Similarly, those who have focused on young graduates have highlighted the importance of economic calculations in decisions about educational mobility. Ackers' (2008) work on intraEuropean mobility, for example, emphasises the role of 'forced mobility' within academia, as junior research staff, in particular, are coerced into moving to secure better funding and pay, while Kennedy's (2010) study of European postgraduates in Manchester, in the UK, concludes that:

the idea that the world was....their oyster and they were more or less free to choose their destination, job experience etc. is highly suspect. Thus, it was the relative paucity of available or promising economic opportunities at home, alongside an expanding service sector in Britain - with vacancies for highly skilled individuals that had induced most to seek new avenues. (p.480) 
Our data indicate that fee differentials (and other economic calculations) were important for some of the young people in our sample. A considerable number of our postgraduates, in particular, were motivated to study overseas, or at least encouraged in their decision to do so, by the lower fees charged by some European countries. Finland, Sweden and the Netherlands were among the places which were seen as particularly attractive in this respect. However, as we have shown above, not all in our sample were equally sensitive to these price differences: those who had studied abroad as undergraduates (or were seriously considering doing so) had rarely been motivated by financial factors and, in most cases, had not been deterred by fees that were significantly higher than they could have expected to pay had they remained within the UK. For these young people, an overseas degree was not seen as part of any cost-saving exercise; instead, it was viewed as a means of accessing elite education, when it was felt such opportunities had been closed down in the UK (Brooks and Waters, 2009) and/or as a route to fun, adventure and excitement (Waters and Brooks, forthcoming; Waters et al., forthcoming). We found similar disparities in relation to the sources of funding that were accessed by the young people to cover the costs of their overseas study. Those who had pursued, or were intending to pursue, undergraduate study abroad were typically dependent on the resources of their immediate family. Despite the very considerable sums involved, this level of financial outlay was rarely seen as problematic - often because they had become used to their parents paying relatively high private school fees throughout their secondary education. Very few of the postgraduate sample were reliant on parental funding in the same way. Instead, the postgraduates commonly drew on a wider range of funding, including scholarships and income derived from part-time work (during their degree and/or in preceding years). They also described various financial struggles and some financial hardship - themes which were notable absent from the undergraduate narratives. 
Despite these important differences between the two parts of our sample and the financial resources to which they had access, it is important not to overlook significant commonalities. As we have argued above, although the postgraduates were, on the whole, less privileged than their undergraduate counterparts in terms of their access to economic capital, both groups were able to draw on significant cultural capital in making their decision to study overseas. Researchers who have explored the higher education choices of students who remain in the UK have pointed to the importance of spatial factors in this process. Reay et al. (2010) have argued that, for working class students in particular, 'staying close to home both geographically and academically provides a sense of safety and reassurance' (p.111-2); geographical proximity can thus offer an important means of negotiating a potentially threatening and unfamiliar university environment. Developing a similar argument, Patiniotis and Holdsworth (2005) contend that:

While a majority of students from middle-class backgrounds appear to experience a relatively smooth and effortless transition to higher education...., students from disadvantaged backgrounds require greater levels of self-determination to 'think outside' familial and community norms. For the latter group, participation in higher education is not only a perceived financial risk, it is also an identity risk. Living at home and maintaining ties with the local community is a way of minimising that risk. (p.92)

With respect to our research, whilst those in postgraduate sample did not have the financial resources of their undergraduate counterparts, they did commonly have the cultural resources which provided the confidence to 'think outside' more standard trajectories. Family experiences of travel, relatives and friends overseas, and contacts provided by former 
teachers and schools all helped to minimise the 'identity risks' of moving abroad to study (Brooks and Waters, 2010). We would also suggest that, although our postgraduate sample was more reliant than the undergraduate sample on scholarships to fund an overseas education, this should not necessarily be seen as indicative of low levels of economic capital. Indeed, as Marcucci and Johnstone (2007) note, scholarships can often be regressive in effect: 'because academic merit or preparedness, at least as conventionally measured, is strongly correlated with socio-economic status, the more "merit" figures into the awarding of grants and subsidised loans...the less is apt to be available for low income students' (p.36).

To conclude, we suggest that while there are important differences between mobile students from the UK in the extent to which they are sensitive to fee differentials and motivated by financial concerns, and in the funding sources they draw upon, this should not obscure the fact that, on the whole, those who cross borders in pursuit of a higher education (at either undergraduate or postgraduate level) are typically privileged in terms of their access to cultural, if not economic, capital. Their familiarity with other cultures and, in many cases, their prior experience of travel minimised the perceived 'identity risks' of studying overseas. Our data suggest, therefore, that despite some differences between students, educational mobility - at least on the part of British students - remains a relatively elitist pursuit. While the newspaper reports that we alluded to at the beginning of the paper may be correct in predicting that some students may respond to the increasing level of tuition fees in the UK by pursuing their higher education abroad, we contend that such avenues are unlikely to be open to all. Indeed, the arguments we have developed in this paper suggest that it may be those who are most able to afford a higher level of fee at home who are most likely to be able to move across geographical borders, to follow a (potentially cheaper) degree elsewhere. 


\section{Acknowledgements}

We are grateful to: the British Academy for funding the research; Helena Pimlott-Wilson for conducting the interviews so well; and all the young adults who gave up their time to talk to us.

\section{References}

Ackers, L. (2008) Internationalisation, mobility and metrics: a new form of indirect discrimination? Minerva, 46, 411-435.

Biffl, G. and Isaac, J. (2002) Should higher education students pay tuition fees? European Journal of Education, 37, 4, 433-455.

Bone, D. (2008) Internationalisation of HE: a ten-year view. Submission to the Department for Industry, Universities and Skills Debate on Higher Education Available at: http://www.bis.gov.uk/wp-content/uploads/2009/10/HE-Internationalisation-Bone.pdf (Accessed 17 December 2010).

Bourdieu, P. (1997) The forms of capital, in: Halsey, A., Lauder, H., Brown, P. and Wells, A. (eds) Education: Culture, Economy, Society Oxford, Oxford University Press. 
Brill, D. (2006) Overseas Attractions, The Guardian 30 August 2006. Available online: http://www.guardian.co.uk/education/2006/aug/30/postgraduate.highereducation?INTCMP= $\underline{\text { SRCH }}$ (Accessed 20 December 2010).

Brooks, R. and Waters, J. (2009) A Second Chance at 'Success': UK students and global circuits of higher education, Sociology, 43, 6, 1085-1102.

Brooks, R. and Waters, J. (2010) Social Networks and Educational Mobility: the experiences of UK students, Globalisation, Societies and Education, 8, 1, 143-157.

Brooks, R. and Waters, J. (2011) Student Mobilities, Migration and the Internationalization of Higher Education Basingstoke, Palgrave.

Brown, R. (2011) The Impact of Markets, in: Brown, R. (ed) Higher Education and the Market London, Routledge.

Browne Report (2010) Securing a Sustainable Future for Higher Education. An Independent Review of Student Funding and Finance. Available online at: http://hereview.independent.gov.uk/hereview/report/ (Accessed 21 January 2011).

Callender, C. (2010) Bursaries and institutional aid in higher education in England: do they safeguard and promote fair access? Oxford Review of Education, 36, 1, 45-62.

Callender, C. and Jackson, J. (2005) Does the fear of debt deter students from higher education? Journal of Social Policy, 34, 4, 509-540. 
Callender, C. and Jackson, J. (2008) Does the fear of debt constrain choice of university and subject of study? Studies in Higher Education, 33, 4, 405-429.

Clark, T. (2006) A free lunch in Uppsala, The Guardian, 24 October 2006.

Deumert, A., Marginson, S., Nyland, C., Ramia, G. and Sawir, E. (2005) Global Migration and Social Protection Rights. The Social and Economic Security of Cross-Border Students in Australia, Global Social Policy, 5, 3, 329-352.

Ertl, H. (2005) Higher Education in Germany: a case of 'uneven' expansion? Higher Education Quarterly, 59, 3, 205-229.

Esping-Anderson, G. (1990) The Three Worlds of Welfare Capitalism Cambridge, Polity Press.

Favell, A. (2008) Eurostars and Eurocities. Free movement and mobility in an integrating Europe Oxford, Blackwell Publishing.

Ferreira, L. and Farkas, E. (2009) The Hungarian student loan scheme: six years of financing access to higher education, Higher Education Review, 41, 2, 23-47.

Findlay, A. and King, R. (2010) Motivations and Experiences of UK Students Studying Abroad BIS Research Paper No.8, London, Department for Business, Innovation and Skills. 
Guth, J. (2008) The opening of borders and scientific mobility: the impact of EU enlargement on the movement of early career scientists, Higher Education in Europe, 33, 4, 395-410.

Hodkinson, P., Sparkes, A. and Hodkinson, H. (1996) Triumphs and Tears: Young People, Markets and the Transition from School to Work London, David Fulton Publishers.

Johnstone, B. (2004) The economics and politics of cost sharing in higher education: comparative perspectives, Economics of Education Review, 23, 403-410.

Kennedy, P. (2010) Mobility, flexible lifestyles and cosmopolitanism: EU postgraduates in Manchester, Journal of Ethnic and Migration Studies, 36, 3, 465-482.

Kenway, J. and Fahey, J. (2007) Policy incitements to mobility. Some speculations and provocations, in: Epstein, D., Boden, R., Deem, R., Rizvi, F. and Wright, S. (eds) Geographies of Knowledge, Geometries of Power: Higher Education in the 21st Century. (World Year Book of Education 2008) New York, Routledge, pp. 161-179.

Li, W. (2007) Family background, financial constraints and higher education attendance in China, Economics of Education Review, 26, 725-735.

Lunt, I. (2008) Beyond tuition fees? The legacy of Blair's government to higher education, Oxford Review of Education, 34, 6, 741-752. 
Marcucci, P. and Johnstone, B. (2007) Tuition fee policies in comparative perspective: theoretical and political rationales, Journal of Higher Education Policy and Management, 29, $1,25-40$.

McCaig, C. (2009) English universities, additional fee income and access agreements: their impact on widening participation and fair access, British Journal of Educational Studies, 57, $1,18-36$.

McMullen, M. (2004) Higher education finance reform in the Czech Republic: transitions in thought and practice, European Education, 36, 2, 74-93.

Morley, L. and Aynsley, S. (2007) Employers, standards and quality in higher education: shared values and vocabularies or elitism and inequalities? Higher Education Quarterly, 61, 229-249.

OECD (2010) Education at a Glance 2010 OECD Publications. Available online at: http://www.oecd.org/document/52/0,3746,en_2649_39263238_45897844_1_1_1_1,00.html (Accessed 17 December 2010)

Ong, A. (1999) Flexible Citizenship: the cultural logics of transnationality Durham, Duke University Press.

Patinoitis, J. and Holsworth, C. (2005) 'Seize that chance!' leaving home and transitions to higher education, Journal of Youth Studies, 8, 81-95. 
Reay, D., Crozier, G. and Clayton, J. (2010) 'Fitting in' or 'standing out': working-class students in higher education, British Educational Research Journal, 36, 1, 107-124.

Salskov-Iverson, D. (2010) Vertical mobility: Danish trends and a case example. Presentation to expert seminar on 'Vertical Mobility', Berlin, 30 November 2010.

Sidhu, R. (2006) Universities and Globalization. To market, to market. New Jersey, Laurence Erlbaum Associates Ltd.

Sussex Centre for Migration Research (2004) International Student Mobility Brighton, Sussex Centre for Migration Research.

Vedrickas, G. (2010) Student fees: the answer may lie overseas, The Observer 10 October 2010. Available online at: http://www.guardian.co.uk/money/2010/oct/10/tuition-feesstudents-overseas-universities?INTCMP=SRCH (Accessed 20 December 2010).

Vossensteyn, H.J.J. (2000) Sharing the cost of higher education in Europe and Australia who pays? Journal of Institutional Research, 9, 2, 54-66.

Waters, J. (2008) Education, Migration and Cultural Capital in the Chinese Diaspora: Transnational Students between Hong Kong and Canada New York, Cambria Press.

Waters, J. and Brooks, R. (forthcoming) 'Vive la différence'? The 'international' experiences of UK students overseas, Population, Space and Place. 
Waters, J., Brooks, R. and Pimlott-Wilson, H. (forthcoming) Youthful escapes? British

students, overseas education and the pursuit of happiness, Social and Cultural Geography.

Weiler, H. (2000) States, markets and university funding: new paradigms for the reform of higher education in Europe, Compare, 30, 3, 33-339.

Welsh, H. (2009) Higher Education Reform in Germany. Advocacy and Discourse, German Politics and Society, 90, 27, 1, 1-23.

Table 1.

Sample of respondents

\begin{tabular}{lcccc}
\hline & Seriously & Completed an & Seriously & Completed a \\
considering an & undergraduate & considering a & postgraduate degree \\
& undergraduate & degree abroad & postgraduate degree & abroad \\
& degree abroad & & abroad & 34 \\
\hline No. of respondents & 20 & 11 & 20 & \\
\hline
\end{tabular}

\footnotetext{
'Although we did not set any specific criteria that students had to meet to be considered as 'seriously considering' overseas study (instead, we relied on self-identification), almost all of those in this part of the sample had, by the time of the interview, taken steps to find out about the places at which they were interested in studying, and the courses they would be able to follow there. Most had also discussed their plans with family members and/or friends. The data suggest that in terms of social and educational background, attitudes and motivations there were no significant differences between those 'seriously considering' overseas study and their counterparts who had already completed a degree abroad.

ii For example, in Findlay and King's (2010) study, under 30 per cent of the UK students in their sample who were studying abroad had attended a state comprehensive school.
} 